\title{
HAK ANAK DALAM SISTEM KEWARISAN ADAT MASYARAKAT SANGLA'BORAN KABUPATEN TORAJA UTARA
}

\author{
Lisma Lumentut ${ }^{1}$, Rosmawati ${ }^{2}$
}

\begin{abstract}
Abstrak
Hukum adat memiliki pengaruh yang besar karena Indonesia sangat kental dengan adat dan kebudayaan masyarakat lokal. Meskipun ekistensi hukum adat perlahan mulai ditinggalkan masyarakat, namun hukum adat masih memiliki peranan yang sangat penting hingga saat ini. Hal ini dikarenakan masyarakat Indonesia yang masih kental dengan adat dan kebiasaan. Dalam masyarakat adat Toraja, budaya yang diwariskan dari nenek moyangnya sangat dipegang teguh dan dipertahankan hingga saat ini, termasuk masalah warisan. Dalam penulisan ini, parmasalahan yang akan diteliti adalah kedudukan anak menurut hukum kewarisan adat pada masyarakat adat Sangla'boran dan peralihan dan pembagian harta warisan terhadap anak pada masyarakat adat Sangla'boran. Metode penelitian yang digunakan adalah penelitiaan hukum sosiologis yuridis dengan menggunakan data primer dan sekunder. Data yang ada kemudian dianalisis secara kualitatif. Kesimpulan dalam penelitian ini adalah kedudukan anak terbagi menjagi enam, yaitu Anak Disibali (anak kandung), Anak Tangdisibali (Anak Pangngan, Anak Bule'), Anak Angkat, Anak Tiri, dan Anak Kemanakan.
\end{abstract}

Kata kunci : anak, hak waris adat Toraja

\section{PENDAHULUAN}

\subsection{Latar Belakang}

Hukum kewarisan adalah himpunan aturan hukum yang mengatur tentang siapa ahli waris yang berhak mewarisi harta peninggalan. Pada prinsipnya kewarisan terjadi didahului dengan adanya kematian, lalu orang yang meninggal tersebut meninggalkan harta warisan yang akan dibagikan kepada ahli warisnya. Peralihan dan pembagian harta peninggalan adalah perbuatan para ahli waris bersamasama, serta pembagian itu diselenggarakan dengan mufakat atau kehendak bersama ahli waris. Masyarakat adat Indonesia mempunyai hukum adat waris sendiri-sendiri. Biasanya hukum adat mereka dipengaruhi oleh sistem kekeluargaan dan sistem perkawinan yang mereka anut.

Masyarakat Indonesia yang terdiri atas beragam suku bangsa memiliki adat istiadat dan hukum adat yang beragam antara yang satu dengan yang lainnya berbeda dan memiliki karakteristik tersendiri yang menjadikan hukum adat termasuk di dalamnya hukum waris menjadi pluralistis pula, namun negara tetap mengakui keberadaan hukum adat yang ada di Indonesia, sebagaimana yang tertuang dalam UUD 1945 Pasal 18B ayat (2) yang berbunyi : "Negara mengakui dan menghormati kesatuan kesatuan masyarakat hukum adat beserta hak-hak tradisionalnya sepanjang masih hidup dan sesuai dengan perkembangan masyarakat dan prinsip Negara Kesatuan Republik Indonesia, yang diatur dalam undang-undang".

Perkembangan hukum nasional di Indonesia di pengaruhi oleh hukum Barat, hukum Islam dan hukum Adat. Ketiga hukum tersebut menjadi dasar dan pedoman dalam pembentukan hukum nasional. Dari ketiga sumber hukum tersebut, hukum adat memiliki pengaruh yang besar karena Indonesia sangat kental dengan adat dan kebudayaan masyarakat lokal. Eksistensi perkembangan hukum adat tidak seperti hukum lainnya. Seiring dengan perkembangan zaman, hukum adat perlahan mulai hilang. Namun, hukum adat masih memiliki peranan yang sangat penting hingga saat ini. Hal ini dikarenakan masyarakat Indonesia yang masih kental dengan adat dan kebiasaan.

Indonesia adalah negara yang kaya akan budaya dan adat, termasuk dalam hal pewarisan. Harta warisan menurut hukum adat bisa dibagikan secara turuntemurun sebelum pewaris meninggal dunia, tergantung dari musyawarah masing-masing pihak. Apabila harta warisan diberikan pada saat pewaris belum meninggal dunia, maka itu disebut pemberian biasa atau dalam hukum islam biasa disebut sebagai hibah. Dengan adanya beragam bentuk sistem kewarisan hukum adat, menimbulkan akibat yang berbeda pula, maka pada intinya hukum waris harus disesuaikan dengan adat dan kebudayaan masing-

\footnotetext{
${ }^{1}$ Dosen Fakultas Hukum Universitas Kristen Indonesia Paulus Makassar

${ }^{2}$ Mahasiswa Fakultas Hukum Universitas Kristen Indonesia Paulus Makassar
} 
masing daerah dengan kelebihan dan kekurangan yang ada pada sistem kewarisan tersebut. Hukum waris adat adalah hukum yang memuat garis-garis ketentuan tentang sistem dan asas-asas hukum waris, tentang harta warisan, pewaris dan ahli waris, serta cara harta warisan itu dialihkan penguasaan dan pemilikannya dari pewaris kepada waris.

Dalam masyarakat adat Toraja, budaya yang diwariskan dari nenek moyangnya sangat dipegang teguh dan dipertahankan hingga saat ini. Hingga pada perkembangannya saat manusia sudah mengalami perkembangan zaman dan mulai mengenal teknologi serta manusia sudah mengerti tentang hukum positif Indonesia, tetapi pada kenyataannya masih banyak daerah-daerah di Toraja yang lebih memilih menjalankan tradisi leluhurnya yang telah diwariskan secara turun. Pada masyarakat Parental (Bilateral) di Tana Toraja yang dikenal dengan sebutan lili'na lepongan bulan gontingna matari' allo atau tondok lepongan bulan tana matari' allo yang artinya negeri yang seluruh bentuk pemerintahannya dan kemasyarakatannya bundar bagaikan bulan dan matahari. Dimana dengan semboyannya misa' kada diputuo pantan kada dipomate yang artinya bersatu kita teguh bercerai kita runtuh, terdapat berbagai macam keunikan atau sistem variasi dalam sistem Parental, adat mengenai hak anak untuk memperoleh hak mewaris selaku anak yang sah dari orang tuanya.

Hal ini memiliki tujuan yaitu untuk melaksanakan penguburan, oleh karena itu penulis mencoba melihat peralihan dan pembagian harta warisan dari berbagai sudut, yang rupanya mempunyai keunikan tersendiri yakni pembagiannya harus sesuai dengan pengorbanan ahli waris pada saat penguburan mayat si pewaris. Maksudnya semakin banyak anak berarti semakin banyak tedong (kerbau) yang akan di kurbankan pada saat upacara penguburan apabila orang tua meninggal, semakin banyak pula harta warisan yang diperoleh ahli waris. Oleh karena itu dipandang perlu untuk melakukan pengkajian lebih lanjut terkait keberlakuan hukum adat mengenai sistem kewarisan adat pada masyarakat Toraja apakah pembagian harta warisan masih sesuai kewarisan adat yang berlaku di Indonesia.

\subsection{Permasalahan}

Berdasarkan uraian diatas, maka yang menjadi permasalahan adalah :

1. Bagaimanakah kedudukan anak menurut hukum kewarisan adat pada masyarakat adat Sangla'boran?

2. Bagaimanakah peralihan dan pembagian harta warisan terhadap anak pada masyarakat adat Sangla'boran?

\subsection{Tujuan Penelitian}

1. Untuk mengetahui kedudukan anak menurut hukum kewarisan adat pada masyarakat adat Sangla'boran.

2. Untuk mengetahui peralihan dan pembagian harta warisan terhadap anak pada masyarakat adat Sangla'boran.

\section{LANDASAN TEORI}

\subsection{Tinjauan Umum tentang Kewarisan \\ 2.1.1. Istilah waris}

Istilah waris didalam hukum kewarisan diambil dari Bahasa Arab yang telah menjadi Bahasa Indonesia, yangberarti bahwa dalam hukum waris adat tidak hanya menguraikan hubungan sematamata dengan ahli waris, namun lebih luas dari itu. Hukum kewarisan adat pada dasarnya merupakan tata cara pengalihan atau penerusan warisan menurut hukum adat yang berlaku. Hukum kewarisan adat pada pokoknya mengatur tentang Pewaris, Warisan, Ahli Waris, serta Pengoperan dan Penerusan harta waris dari pewaris kepada ahli warisnya. Hal ini sebagai konsekuensi atas berlakunya dan masih terpeliharanya hukum adat di beberapa daerah di Indonesia sebagai bagian kekayaan budaya Indonesia. Hukum kewarisan adat merupakan suatu peraturan yang mengatur masalah pewarisan adat. Menurut Soepomo, hukum kewarisan adat memuat peraturan-peraturan yang mengatur proses meneruskan serta mengoperkan barang-barang harta benda dan barang-barang yang tidak berwujud benda (immateriele goederen) dari siuatu angkatan manusia (generatie) kepada keturunannya.

Hukum waris adat pada dasarnya merupakan hukum kewarisan yang bersendikan prinsip-prinsip komual atau kebersamaan sebagai bagian dari kepribadian bangsa Indonesia. Prinsip kebersamaan dalam hukum kewarisan adat tidak mengenal bagian-bagian tertentu untuk para ahli waris dalam sistem pembagiannya. Teer Haar Dalam bukunya yang berjudul "Beginselen en stelsel van het adatrecht" Teer 
Haar merumuskan bahwa hukum kewarisan adat adalah "Het adaterfecht de rechtsregelen, welke berrekking hebben op het boeiende, eeuwige proces van doorgeven en overgaan van het materiele en immateriele vermogen van generatie op generatie," yang artinya "Hukum waris adat adalah aturanaturan hukum yang mengenai cara bagaimana dari abad keabad penerusan dan peralihan dari harta kekayaan yang berwujud dan tidak berwujud dari generasi pada generasi."

Harta warisan menurut hukum adat tidak merupakan kesatuan yang dapat dinilai harganya, tetapi merupakan kesatuan yang tidak terbagi atau dapat terbagi menurut jenis macamnya dan kepentingan para ahli warisnya. Harta warisan adat tidak boleh dijual sebagai kesatuan dan uang dan uang penjualan itu dibagi-bagikan kepada para waris menurut ketentuan yang berlaku sebagaimana yang berlaku dalam hukum waris Islam dan Barat.

\subsubsection{Sistem Kewarisan Adat Indonesia}

Hukum keluarga adat mengenal adanya tiga sistem keturunan, yang pada dasarnya berpengaruh terhadap sistem kewarisan adat. Secara teoretis sistem kekerabatan dapat dibedakan dalam tiga bagian yaitu: 1) Sistem patrilinial, yaitu sistem keturunan yang di tarik menurut garis bapak, dimana kedudukan pria lebih menonjol pengaruhnya dari kedudukan wanita didalam pewarisan (Gayo, Alas, Batak, Lampung, Nusa tenggara), 2) Sistem matrilinial, yaitu sistem keturunan yang ditarik menurut garis ibu, dimana kedudukan wanita lebih menonjol pengaruhnya dari kedudukan pria didalam pewarisan (Minangkabau, Engano, Timor), 3) Sistem parental atau bilateral, yaitu sistem keturunan yang ditarik menurut garis orang tua, atau menurut garis dua sisi (bapak-ibu) dimana kedudukan pria dan wanita tidak dibedakan didalam pewarisan (Aceh, Sumatra timur, Riau, Jawa, Kalimantan, Sulawesi, dan lain lain). Dalam buku Prof. H. Hilman Hadikusuma, S.H., Hazairin menyatakan: " Hukum waris adat mempuyai corak tersendiri dari alam fikiran masyarakat yang tradisional dengan bentuk kekerabatan yang sistem keturunannya patrilinial, matrilinial, parental atau bilateral."

Hukum Kewarisan Adat mengenal adanya tiga sistem kewarisan, yaitu sebagai berikut:

1) Sistem kewarisan individual kewarisan dengan sistem individual atau perseorangan adalah sistem pewarisan dimana setiap waris mendapatkan pembagian untuk dapat menguasai dan atau memiliki harta warisan menurut bagiannya masing-masing,

2) Sistem Kewarisan kolektif, dimana harta peninggalan diteruskan dan dialihkan pemilikannya dari pewaris kepada waris sebagai kesatuan yang tidak dapat dibagi-bagi penguasaan dan pemilikannya melainkan setiap waris berhak untuk mengusahakan menggunakan atau mendapat hasil dari harta peninggalan itu. Sistem kewarisan ini biasanya berlaku didaerah Minangkabau, Batak dan Minahasa,

3) Sistem kewarisan mayorat, adalah sistem kewarisan kolektif, hanya penerusan dan pengalihan hak penguasaannya atas harta yang tidak dibagi-bagi itu dilimpahkan kepada anak tertua yang bertugas sebagai pemimpin rumah tangga atau kepala keluarga menggantikan kedudukan ayah atau ibu sebagai kepala keluarga. Kelemahan dan kebaikan sistem mayorat terletak pada kepemimpinan anak tertua dalam kedudukannya sebagai pengganti orang tua yang telah wafat.

Pewaris dan ahli waris menurut hukum kewarisan adat.

a. Pewaris adalah orang yang memiliki harta kekayaan, yang merupakan dasar dalam pembagian warisan bagi keturunan anakanaknya. Tujuan pewaris mengoperkan harta warisannya ini tidak lain adalah untuk menjaga keselamatan dan kesinambungan dari hak miliknya supaya terjaga dan dapat dimanfaatkan seefisien mungkin. Pewaris yang telah meninggal dunia meninggalkan sesuatu yang dapat beralih kepada keluarganya yang masih hidup, baik keluarga melalui hubungan kekerabatan, perkawinan maupun keluarga melalui persekutuan hidup dalam rumah tangga. pengalihan harta kepada keluarga yang di sebutkan terakhir ini, biasanya bersifat jaminan keluarga yang di berikan oleh ahli waris melalui pembagiannya.oleh karena itu yang tergolong sebagai pewaris adalah: Orang tua (ayah dan ibu), saudara-saudara yang belum berkeluarga, Suami dan/atau Istri .

b. Ahli waris dapat diartikan sebagai orang yang berhak mewarisi harta peninggalan pewaris, dengan mengenyampingkan orang lain berdasarkan hubungan keluarga antara pewaris dan ahli waris.

\subsection{Kedudukan Anak Menurut Kewarisan Adat}

\section{Anak kandung}

Adalah anak yang lahir dari kandungan ibu dan ayah kandungnya. Kedudukan anak kandung sebagai warisnya dipengaruhi oleh perkawinan yang dilakukan kedua orang tuanya. Jika perkawinan ayah 
dan ibu sianak sah, maka anaknya sah sebagai waris, sebaliknya jika perkawinan ayah ibu sianak tidak sah atau anak lahir diluar perkawinan, maka anak menjadi tidak sah sebagai waris dari orang tua kandungnya.

2. Anak Angkat

Ada beberapa hal yang mendorong seseorang mengangkat anak angkat yaitu, mungkin karena orang tua angkat tidak mempunyai anak atau mandul, mungkin pula untuk mempererat hubungan kekeluargaan. Menurut Mr. B. Wirjono Projodikoro (1983:22) mengemukakan bahwa anak angkat adalah seorang bukan dari turunan dari kedua belah pihak suami isteri yang diambil, dipelihara, dan diperlakukan oleh mereka sebagai anak turunannya sendiri.

3. Anak Tiri

Anak tiri adalah anak yang bukan hasil kandungan suami isteri yang bersangkutan, tetapi merupakan anak bawaan didalam perkawinan, dikarenakan sebelum perkawinan salah satu pihak atau bersamasama pernah melakukan perkawinan dan mempunyai anak, kemudian si anak di bawa masingmasing dalam kehidupan rumah tangga setelah mereka mengikat tali perkawinan. Pada dasarnya anak tiri bukan waris dari ayah tiri atau ibu tirinya, tetapi ia adalah ahli waris dari ayah dan ibu kandungnya sendiri.

\subsection{Harta Warisan}

Menurut pengertian yang umum warisan adalah semua harta benda yang ditinggalkan oleh seorang yang meninggal dunia (pewaris), baik harta benda itu sudah dibagi atau belum terbagi, atau memang tidak terbagi. Di lingkungan masyarakat adat yang asas pewarisannya individual, apabila pewaris wafat maka semua anggota keluarga baik pria atau wanita, baik tua atau muda, baik dewasa atau anak-anak, pada dasarnya setiap waris berhak atas bagian warisannya. Berkumpulnya para anggota keluarga ketika atau setelah pewaris wafat bukan saja dikarenakan kewajiban mengurus wafatnya pewaris, tetapi juga dikarenakan adanya hak waris. Disamping itu memang ada harta warisan yang memang tidak dapat dibagi-bagikan penguasaan atau pemilikannya dikarenakan sifat benda, keadaan dan kegunaannya tidak dapat dibagi, misalnya harta pusaka, alat perlengkapan adat, senjata, jimat, ilmu gaib, jabatan adat, gelar adat, dan sebagainya yang harus dipegang oleh waris tertentu dan dimanfaatkan untuk kepentingan bersama.

Menurut L.T. Tandilintin, Tana Toraja mengenal beberapa jenis harta warisan, yaitu :

1) Harta asal, yaitu harta yang diperoleh suami dan isteri dari masingmasing orang tuanya, baik sebagai warisan maupun yang bukan warisan. Misalnya yaitu tanah perumahan atau dalam bahasa toraja dikenal dengan istilah Inan Banua, sawah yang dikenal dengan istilah Uma, dan ladang yang dikenal dengan $P a^{\prime} l a k$. Harta asal suami dan isteri tidak dipisahpisahkan melainkan di pergunakan untuk kebutuhan bersama selama perkawinan itu berlangsung,

2) Harta pembujangan, adalah harta diperoleh masing-masing suami dan isteri yang disebut Pandaka' Belangna. Harta benda ini dapat berupa tanah, perhiasan, dan ternak serta alat-alat rumah tangga. Selama perkawinan itu berlangsung harta tersebut disatukan baik dari suami maupun isteri. Sama halnya dengan daerah lain, di daerah toraja juga tidak mengenal pemisahan harta benda antara suami dan isteri selama perkawinan berlangsung, baik harta yang berasal dari pewarisan maupun harta benda yang didapat sendiri selama orang tersebut belum menikah, harta ini biasa disebut dengan harta pembujangan atau dalam bahasa toraja dikenal dengan sebutan Pandaka' Belangna. Akan tetapi terjadi apabila terjadi perceraian antara suami dan isteri maka harta pembujangan tersebut dipisahkan dan kembali kepada pemiliknya masing-masing,

3) Harta pencarian bersama, adalah harta yang diperoleh atau harta yang didapat suami dan isteri bersama selama, selama masa perkawinan. Harta pencarian bersama ini dalam bahasa toraja disebut dengan harta Rampanan Kapa', atau Pandaka' Nasibali. Suami atau isteri juga mempunyai hak yang sama atas harta perkawinan tersebut. Meskipun suami merupakan kepala keluarga, ia tidak dapat bertindak sendiri atas harta perkawinan tersebut. Apabila suami ingin menjual harta perkawinan untuk memenuhi kebutuhannya ia harus mendapat persetujuan dari sang isteri, begitupun sebaliknya isteri wajib meminta persetujuan terlebih dahulu kepada suami untuk menjual harta perkawinan dalam pemenuhi kebutuhannya. Jadi, jika ada salah satu pihak tidak menyetujui maka harta tersebut tidak dapat di jual. Apabila terjadi perceraian maka harta pencarian tersebut dibagi menjadi dua. Apabila suami dan isteri memiliki anak, maka harta tersebut dibagi secara merata artinya baik bapak, 
ibu, dan anak mendapatkan jumlah harta yang sama. Setelah suami dan isteri meninggal maka harta pencarian bersama tersebut disatukan kembali dan menjadi harta warisan bagi si anak,

4) Harta pusaka, adalah harta milik bersama yang tidak dapat dibagi-bagi oleh para ahli waris tetapi dapat dipergunakan oleh salah satu pihak apabila diperlukan. Misalnya renovasi pada rumah adat atau dalam bahasa toraja disebut dengan Bапиа Tongkonan, acara pesta kematian atau dalam bahasa toraja dikenal dengan Rambu Solo', dan juga pada pesta perkawinan atau syukuran disebut Rambu $T u k a$ '. Menurut beberapa orang yang dituakan di daerah toraja, pada awalnya harta pusaka itu dimiliki oleh orang yang mempunyai kesaktian. Harta pusaka itu misalnya senjata tajam yang berbentuk parang yang disebut $L a$ 'bo' Todolo, dan selembar kain using yang berumur ratusan tahun dalam bahasa toraja disebut $M a w a$ ', serta kalung yang disebut Manik. Barangbarang tersebut tetap utuh dan tidak dapt terbagi-bagi dan disimpan dalam rumah adat atau Banua Tongkonan. Tujuan disimpannya harta pusaka dalam rumah adat, adalah untuk menjaga keamanan atau menghindari pemilikan secara pribadi akan tetapi dimiliki bersama-sama bagi mereka yang masih memiliki hubungan keluarga dalam rumah adat tersebut.

\subsubsection{Pengalihan dan pembagian harta warisan}

Pengalihan atau pembagian harta waris dilakukan dengan dua cara pembagian, yaitu hibah, dan hibah wasiat. Hibah adalah jenis pembagian suatu benda atau harta seseorang kepada orang lain tanpa mengharapkan imbalan, dan penguasaan atas benda atau harta tersebut telah beralih secara langsung. Sedangkan Hibah wasiat adalah harta yang didapat dari seseorang yang wafat.

Dalam konteks pembagian harta warisan, hukum adat tidak menentukan kapan waktu harta warisan itu akan dibagi atau kapan sebaiknya diadakan pembagian, begitu pula siapa yang menjadi juru bagi tidak ada ketentuannya. Menurut adat kebiasaan waktu pembagian setelah wafat pewarisan dapat dilaksanakan setelah upacara sedekah atau hari keseratus karena pada waktu tersebut para anggota waris berkumpul. Apabila harta warisan akan dibagi maka yang menjadi juru bagi dapat di tentukan antara lain: Orang tua yang masih hidup (janda atau duda dari pewaris), Anak tertua lelaki atau petempuan, atau Anggota keluarga tertua yang dipandang jujur, adil, bijaksana, Anggota kerabat tetangga, pemuka masyarakat adat atau pemuka agama yang diminta, ditunjuk atau dipilih para waris untuk bertindak sebagai juru bagi.

Hukum adat tidak mengenal cara pembagian dengan perhitungan matematika, tetapi selalu didasarkan atas pertimbangan mengingat wujud benda dan kebutuhan waris bersangkutan. Jadi walaupun hukum waris adat mengenal asas kesamaan hak tidak berarti bahwa setiap waris akan mendapat warisan dengan jumlah yang sama.

Menurut L.T.Tandilintin, di daerah Tana Toraja mengenal beberapa proses pembagian harta warisan, yaitu pemberian pewaris pada waktu masih hidup dan dilakukan sewaktu waktu yang disebut Tekken. Tekken juga adalah suatu pemberian biasa atau hibah biasa yang dapat dilakukan pada sewaktuwaktu. serta Mana' atau $B a$ 'gi yaitu pembagian warisan berbentuk wasiat yang ditinggalkan pewaris dalam bentuk pesan mengenai harta warisan dan harta tersebut baru dapat diterima ketika pewaris meninggal dunia.

Perbuatan salah yang memungkinkan hilangnya hak mewaris terhadap seseorang terhadap harta warisan orang tuanya atau dari pewaris lainnya adalah misalnya di karenakan sebagai berikut: membunuh atau berusaha menghilangkan nyawa pewaris atau anggota keluarga pewaris, melakukan penganiayaan atau berbuat merugikan kehidupan pewaris, melakukan perbuatan tidak baik, menjatuhkan nama baik pewaris atau nama kerabat pewaris karena perbuatan yang tercela, murtad dari agama atau pindah agama dan kepercayaan dan sebagainya.

\section{METODE PENELITIAN}

\subsection{Lokasi Penelitian}

Penelitian ini dilaksanakan di La'bo Kabupaten Toraja utara, Sulawesi Selatan dengan mengambil daerah tertentu sebagai sumber data yaitu Kecamatan Sangalangi, Desa Linda. Pemilihan lokasi ini didasarkan pada kemudahan akses untuk memperoleh informasi yang dibutuhkan sebab di daerah tersebut masih sangat kental pelaksanaan hukum adat, utamanya yang berkaitan dengan permasalahan dalam penelitian ini.

\subsection{Jenis dan Sumber Data}


Jenis dan sumber data yang digunakan dalam penelitian ini adalah:

Data Primer adalah data yang diperoleh di lapangan melalui wawancara (interview). Wawancara dilakukan kepada narasumber yang terkait dengan penelitian ini seperti tokoh masyarakat, maupun tokoh atau pemangku adat.

Data Sekunder yaitu data yang diperoleh melalui studi pustaka berupa buku-buku, karya ilmiah, internet dan lai-lain yang terkait dengan masalah yang diteliti. penelitian ini, yakni Hukum Kewarisan Adat, Hukum Kewarisan Islam, Hukum Kewarisan Perdata Barat serta data yang diperoleh dari media elektronik yang berhubungan dengan masalah dalam penelitian ini.

\subsection{Teknik Pengumpulan Data}

1. Teknik Observasi adalah pengumpulan data yang dilakukan dengan sengaja, sistematis mengenai fenomena social dan gejala-gejala pisis untuk kemudian dilakukan pencatatan. Dalam kaitannya dengan penelitian ini penulis langsung terjun kelapangan menjadi partisipan untuk menemukan (observer partisipatif) untuk menemukan dan mendapatkan data yang berkaitan dengan fokus penelitian, yaitu bagaimana Hak Anak Dalam Sistem Kewarisan dan Cara Pembagian Warisan.

2. Studi Wawancara

Wawancara yaitu teknik yang dilakukan dengan cara membuat pedoman wawancara yang disusun dalam bentuk pertanyaan.

\subsection{Analisis Data}

Data yang diperoleh di lapangan akan dianalisis sesuai dengan karakteristik data yang bersangkutan. Untuk data yang terkumpul baik primer dan sekunder akan dijelaskan secara deskriptif, yaitu dengan menjelaskan, menguraikan dan menggambarkan permasalahan yang berkaitan erat dengan penelitian ini. Sehingga akan menjadikan datanya dapat dengan mudah dipahami dan menjawab masalah-masalah yang ada.

\section{HASIL DAN PEMBAHASAN}

\subsection{Kedudukan anak dalam mewaris pada masyarakat adat Sanglabo'ran.}

Dalam masyarakat adat Sangla'boran dikenal adanya beberapa macam anak untuk mengetahui kedudukan tiap-tiap anak mengenai harta warisan. Sesuai dengan hasil wawancara dengan To parengge, yang bernama Ne' Kassang mengatakan bahwa: "pembagian warisan ditentukan oleh kedudukan seorang pewaris dalam hubungan keturunan dengan anak yang bagi masyarakat Sanglaboran adalah hal yang sangat penting dalam pertumbuhan masyarakat".

Dalam masyarakat Sanglabo'ran setiap anak memiliki hak atas harta warisan berbeda-beda olehnya itudi tetapakan adanya pemisahan antara status anak atas harta warisan. Dengan demikian dikenal ada enam macam anak yaitu :

1. Anak Disibali, adalah anak yang lahir dalam ikatan perkawinan antar seorang laki-laki dan seorang perempuan, dengan kata lain anak disibali adalah anak yang sah karena ia dilahirkan oleh seorang perempuan yang mempunyai suami. Jadi jelas bahwa anak disibali ialah anak yang dilahirkan dalam ikatan perkawinan antara seorang laki-laki dan seorang perempuan.

2. Anak Tangdisibali, adalah anak yang lahir diluar ikatan perkawinan, dengan kata lain anak tangdisibali adalah anak tidak sah karena tidak memiliki ayah yang jelas. Bagian dari anak tangdisibali yaitu:

a. Anak Pangngan, adalah anak yang dilahirkan karena perhubungan kelamin atau persetubuhan antara seorang laki-laki dan seorang perempuan tanpa melalui suatu ikatan perkawinan, akan tetapi anak-anak tersebut tetap di akui oleh ayahnya.

b. Anak Bule', adalah anak yang dilahirkan dari hubungan gelap antara seorang laki-laki yang tidak diketahui, ibu anak ini disebut dengan kia 'tang bule'. Dengan kata lain anak Bule' adalah anak yang lahir dari seorang perempuan akan tetapi tidak ada seorangpun laki-laki yang bersedia mengakui sebagai anaknya, karena anak tersebut tidak diketahui siapa ayahnya, namun yang jelas ia hanya mempunyai ibu.

3. Anak angka', adalah seorang anak yang diangkat oleh orang tua angkatnya karena tidak memiliki anak atau anak tersebut sudah tidak memiliki orang tua lagi. Biasanya pengangkatan anak ini dimulai sejak anak itu masih bayi. 
4. Anak Tiri, adalah anak yang lahir dari perkawinan sebelumnya yang dibawa oleh ayah atau ibu masuk kedalam perkawinan barunya.

5. Pa'nakan, adalah kemanakan atau anak saudara kandung pewaris, baik dari saudara perempuan maupun saudara laki-laki pewaris.

6. Anak Piara atau anak Disarak, adalah anak yang diambil oleh pewaris untuk di pelihara dengan kata lain orang tua piaraannya lah yang berhak untuk memelihara anak tersebut layaknya anak kandung. Anak piara ini biasanya terjadi pada anak yang dewasa atau anak yang lagi tidak menyusui dari ibu kandungnya.

\subsubsection{Anak Disibali}

Anak disibali berkedudukan sebagai pewaris yang utama, baik terhadap ayahnya maupun terhadap ibunya. dapat juga dikatakan bahwa disibali adalah anak yang mempunyai kedudukan yang paling utama, yang sering disebut Sarume. Karena pada dasarnya sanak keluarga tidak dapat menjadi ahli waris apabila pewaris mempunyai anak. Selain itu anak disibali adalah ahli waris golongan sarume yang dapat mengenyampingkan sanak keluarganya yang lain yaitu golongan kedua yang sering disebut golongan lugpang (hasil wawancara dengan Ne'Kassang). Hasil wawancara dengan Kepala Lembang yang bernama Y.T. Tasik Rede mengatakan : "Berdasarkan hubungan kekeluargaan (pertalian darah) antara pewaris dan anak disibali bukanlah persoalan, apakah anak disibali itu adalah anak laki-laki atau anak perempuan karena baik anak laki-laki atau anak perempuan mempunyai hak atas harta kekayaan orang tua yang sama".

Dalam sistem kekeluargaan di daerah Sangla'boran berlaku sistem kekeluargaan parental dimana tidak diperhitungkannya baik dari pihak laki-laki maupun dari pihak perempuan. Dengan demikian anak disibali mempunyai hak atas harta asal, harta pembujangan yang disebut Pandaka' belangna, harta perkawinan disebut Torakna rampanan kapa',dan harta pusaka disebut Mana' yang dimiliki oleh orang tua. Hasil wawancara bersama To Indo', menjelaskan bahwa proses pewarisan kepada anak disibali dapat terjadi pada waktu pewaris masih hidup dengan cara memberikan kepada anak tersebut bagian tertentu dari harta kekayaannya, yang sering disebut $B a^{\prime}$ 'gi yang bertujuannya agar anaknya dapat melaksanakan pesta kematian apabila si pewaris meninggal dunia, akan tetapi hal ini tidak mengikat kepada ahli waris. Selain itu Ba'gi juga bertujuan sebagai pegangan atau modal untuk dapat hidup mandiri.

Wawancara dengan Petoe Songkang (aluk) yang bernama To indo, mengatakan: "Ba'gi dapat diberikan kepada kepada anak yang sudah atau akan berumah tangga, anak yang telah dipertunangkan atau dalam bahasa toraja disebut Ma'parampo, dan juga kepada anak yang belum kawin". Jadi dapat dikatakan Ba'gi itu adalah merupakan hadiah orang tua kepada anak-anaknya atau kepada ahli warisnya agar dikemudian hari mereka dapat berdiri sendiri dalam membina rumah tangganya.

Dalam pelaksanaan pesta kematian pewaris anak Disibali, memegang peran penting karena anak tersebutlah yang menentukan siapasiapa yang ikut memotong hewan dalam upacara pesta kematian pewaris apakah kerbau atau babi hal ini sering disebut dengan Mantunu atau sering juga disebut $M a$ ' tallang namun hal ini dilakukan bukan untuk memperoleh harta warisan. Menurut hukum adat kecamatan sanggalangi yang dapat Mantunu (memotong kerbau atau babi) ialah anak disibali serta keluarga yang mempunyai hubungan darah dengan pewaris. Namun tidak semua orang atau keluarga dapat diperbolehkan Mantunu pada pesta kematian pewaris akan memperoleh harta warisan, melainkan hanya anak Disibali dan keluarga yang dekat hubungan darahnya dengan pewaris atau tergantung pada kesepakatan keluarga. Keluarga yang lain dapat Mantunu dengan tujuan Ma'tete rara buku atau kesiumpuranan rara bukunna yaitu mendekatkan hubungan kekeluargaan atau hubungan darah, akan tetapi tidak mendapat harta warisan dari peninggalan pewaris. Tetapi apabila keluarga yang datang Mantunu meninggal dunia, maka ahli waris tersebut juga ikut Mantunu pada pesta penguburannya.

Apabila pewaris meninggalkan anak yang masih kecil atau belum dewasa, sedangkan harta warisan peninggalan pewaris akan dibagi oleh para ahli warisnya maka bagian anak tersebut biasanya diberikan sebagian kecil dari harta warian itu. Jika anak yang belum dewasa itu dipelihara oleh keluarga lain maka bapak piaranya dapat mewakilinya untuk mengambil bagian dari harta tersebut. Kalau anak disibali masih ada dalam kandungan pada waktu ayahnya meninggal dunia, belum berhak atas harta warisan akan tetapi apabila ada pembagian warisan, anak tersebut tetap diperhatikan dan biasanya disediakan sebagian kecil dari harta warisan itu. 
Anak yang masih dalam kandungan dalam bahasa toraja disebut Uwai lampa tambuk, artinya belum jadi manusia yang dapat memikul tanggung jawab dalam pesta kematian pewaris. Anak yang masih kecil disebut Uwai diongpa dongka, artinya masih seperti air didaun talas yang berarti belum dapat diharapkan sepenuhnya, dan juga belum sanggup memikul tanggung jawab dalam pesta kematian pewaris, namun tetap di perhatikan apabila ada pembagian warisan. Hasil wawancara bersama To Parengnge yang bernama Ne' Sedan, mengatakan Bahwa: "Besar kecilnya bagian masing-masing ahli waris tidak tidak tergantung pantunuan pada pesta penguburan pewaris".

Jadi dalam hal ini, harta warisan dibagi sesuai dengan kesepakatan keluarga atau ahli waris bukan berdasarkan pengorbanan dari tiap-tiap ahli waris, walaupun kini pembagiannya dibagi secara merata namun pada prakteknya anak sulunglah yang terkadang mendapatkan harta warisan lebih banyak dari saudara-saudara lainnya karena adanya beberapa pertimbangan, diantaranya karena anak sulung lebih berat memikul beban tanggung jawab terhadap saudara-saudaranya, dimana ia berperan sebagai kakak dan sekaligus orang tua bagi saudaranya yang lain.

\subsubsection{Anak Tangdisibali}

\section{Anak Pangngan}

Anak Pangngan adalah ahli waris dari ibu dan ayahnya yang mengakuinya, antara anak Pangngan dan anak Disibali terdapat perbedaan yang menyangkut harta kekayaan orang tua, karena anak Pangngan bukanlah orang yang menentukan siapa-siapa yang boleh mewaris dari harta kekayaan orang tuanya, melainkan yang menentukan adalah anak Disibali. Hasil wawancara bersama To Parengge yang bernama, mengatakan bahwa : "Anak Pangngan hanya berhak atas harta asal, harta pusaka, dan harta pembujangan yang disebut Pandaka' belangna dari orang tuanya, Akan tetapi harta perkawinan pada dasarnya anak pangngan tidak berhak sama sekali tergantung dari belas kasihan saudarasaudaranya (anak Disibali)".

Dengan demikian dapat dikatakan bahwa anak pangngan dapat mewarisi dari harta perkawinan dengan ketentuan terlebih dahulu ada persetujuan dari anak disibali. Seperti halnya anak Disibali anak Pangngan adalah ahli waris golongan Sarume yang berhak atas harta kekayan orang tuanya meskipun tidak dapat mewarisi harta perkawinan. Untuk menghindari perselisihan antara anak Pangngan dan anak Disibali, maka pewaris sebelum meninggal dunia biasanya menentukan harta kekayaan yang termasuk harta asal, harta pembujangan, harta pusaka, dan harta perkawinan. Sebab apabila pewaris tidak berbuat demikian maka ada kemungkinan timbul perselisihan antara anak Disibali dan anak Pangngan. Anak Pangngan tidak berhak atas harta perkawinan orang tuanya, jadi proses pewarisan dapat terjadi pada waktu pewaris masih hidup yang berupa Tekken.

Anak Pangngan mempunyai kedudukan yang cukup penting dalam pelaksanaan pesta kematian pewaris karena anak Pangngan bersamasama dengan anak Disibali sebagai Ampusara', artinya sebagai pelaksana pesta penguburan pewaris, olehnya itu anak Pangngan dapat Mantunu untuk dapat memperoleh harta warisan yang tidak termasuk harta perkawinan. Jika anak Pangngan tidak turut dalam pesta penguburan pewaris, maka mereka tetap mendapat bagian dari harta peninggalan pewaris yang bukan harta perkawinan. Tekken yang diberikan pewaris sewaktu ia masih hidup tidak dapat dicabut kembali oleh saudara-saudaranya sekalipun anak Pangngan tidak ikut serta dalam pesta kematian pewaris.

2. Anak Bule'

Anak Bule' adalah anak yang lahir tanpa diketahui siapa ayahnya atau dalam bahasa Toraja disebut Anak Tangke Ambe'. Anak bule' juga hampir sama dengan anak Tepo' dimana tidak diketahui siapa ayah kandungnya. Hanya saja anak Tepo lahir dengan memiliki dua orang ayah hal ini akibat dari ibu yang menikah sewaktu ia masih mengandung dari suami pertama, dan suami kedua mengakui jika anak yang dikandung oleh isterinya tersebut adalah dara dagingnya sendiri. Anak bule' adalah ahli waris dari ibunya atas harta asal, harta pusaka, dan harta pembujangan ibunya. Jadi kedudukan anak Bule' ini atas harta kekayaan orang tunya dalam hal ini ibunya, tidak menimbulkan persoalan sebab anak tersebut dipandang tidak memiliki ayah.

\subsubsection{Anak Angka}

Anak angka' atau anak adopsi ialah mengangkat anak orang lain atau saudara untuk diperlakukan sebagai anak sendiri. Hasil wawancara dengan Petoe Songkang yang di kenal dengan nama To Indo, mengatakan bahwa : "adopsi anak disebut Todiala anak atau Rambunan Tama Batang /To dibuang 
tama tambuk dengan kata lain bahwa anak angkat tersebut telah dianggap lahir dari rahim ibu angkatnya sendiri”. Beberapa hal yang mendorong orang mengangkat anak antara lain, yaitu: karena orang tersebut tidak memiliki anak atau mandul, yang disebut To Tamanang, mempererat hubungan kekeluargaan, mempererat persahabatan antara orang tua kandung dan orang tua angkat, perlindungan jasmani dan materi, ingin mendapatkan perhubungan kekayaan karena tidak mempunyai pengaruh dengan orang bangsawan yang berkuasa dalam masyarakat. Hasil wawancara dengan To Parenge' yang bernama Ne' Koton, merngatakan bahwa: "Seorang anak yang telah diangkat berkedudukan sebagai ahli waris terhadap orang tua angkatnya".

Jadi dalam masyarakat sangla'boran hubungan antara anak dengan orang tua kandungnya dari segi pemeliharaan terhadap anak tersebut telah terputus, karena pemeliharaan terhadap anak tersebut telah diambil alih oleh orang tua angkatnya sehingga tugas orang tua kandungnya telah beralih pula kepada orang tua angkatnya. Tetapi dalam segi kedudukannya sebagai seorang anak kandung dari orang tua kandungnya tidak terputus oleh karena itu anak angkat tersebut masih dapat menjadi ahli waris dari orang tua kandungnya.

Hasil wawancara bersama to parenge' yang bernama Ne' Kassang, mengatakan bahwa : "Anak angkat sering juga disebut dengan To Ma'dua Bubun Massaruran Patomali. Ma' dua bubun artinya mempunyai dua sumur, sedangkan Massaruran Patomali artinya menerima aliran dari dua arah". Maksud sebenarnya adalah bahwa seorang anak angkat menerima warisan dari dua sumber yaitu dari orang tua angkatnya dan orang tua kandungnya sendiri. Untuk sah nya suatu tindakan pengangkatan anak harus melalui suatu upacara adat yang biasa disebut $M a^{\prime} k u$ 'kui yang berarti mengunduli kepala. Upacara adat ini biasa dimulai dengan memotong seekor babi sebagai tanda persembahan pada yang Maha Kuasa dengan tujuan agar upacara tersebut mendapat berkah.

\subsubsection{Anak Tiri}

Anak tiri atau yang dalam bahasa toraja disebut Anak Poro adalah anak seorang suami atau isteri, tetapi dengan ibu atau bapak lain. Di daerah penelitian penulis, anak tiri bukanlah ahli waris dari ibu atau bapak tirinya, tetapi dalam prakteknya anak tiri dianggap sebagai anak sah dari ibu atau bapak tirinya apalagi jika ibu atau bapak tirinya tidak memiliki keturunan. Dengan demikian anak tiri sudah dianggap sebagai ahli waris dari ibu atau bapak tirinya. Kedudukan anak tiri atas harta kekayaan orang tua kandungnya adalah sebagai ahli waris baik dari harta asal, harta pusaka, harta pembujangan, namun terhadap harta perkawinan ia hanya memperoleh hak sebagian sepanjang ia tidak mempunyai saudara. Karena ia dibatasi oleh Pandaka' Dolo Anak Dolo, Pandaka' Undi Anak Undi yang berarti harta yang diperoleh pada perkawinan pertama adalah untuk anak pertama demikian pula terhadap harta yang diperoleh dalam ikatan perkawinan yang berikutnya adalah anak yang berikutnya pula.

\subsubsection{Anak Kemanakan}

Anak kemanakan adalah anak saudara pewaris baik saudara laki-laki melainkan saudara perempuan. Anak keponakan tidak berhak untuk menjadi ahli waris kecuali pewaris tidak mempunyai anak kandung atau anak maka keponakan berkedudukan sebagai Sarume sebab tidak ada ahli waris yang lebih dekat terhadap pewaris. Dalam hal ini keponakan bertanggung jawab atas upacara penguburan pewaris, tetapi jika pewaris meninggalkan anak kandung maka kedudukan anak keponakan tidak berkedudukan sebagai golongan Sarume tetapi berkedudukan sebagai golongan Lu'pang, dan ia dapat ikut serta dalam kegiatan memotong kebau atau babi yang sering disebut Mantunu, tetapi tidak untuk mendapatkan harta warisan.

\subsubsection{Anak Piara (Anak Di sarak)}

Anak Piara adalah anak orang lain yang diambil untuk selanjutnya dipelihara dan dididik sebagaimana layaknya anak kandung. Hal-hal yang mendorong orang untuk mengambil anak piara antara lain: untuk membantu dalam rumah tangga, karena ia mandul, sebagai penghibur karena sangat menyukai anak kecil. Anak Piara atau anak di Sarak tidak berkedudukan sebagai ahli waris dari orang tua piaranya, karena ia hanya di pelihara dan bukan dijadikan anak angkat, tetapi ia dapat diberi Bagi' misanya sebidang sawah dan apabila ia telah mendapat Ba'gi maka kedudukannya beralih dari anak piara menjadi anak Ba'gi. Oleh karena itu anak Piara yang telah menerima hadiah dapat menjadi Ampusara' dimana ia dapat memotong kerbau atau babi apabila orang tua piaranya meninggal dunia, dan harta yang diperolehnya sebagai hadiah tidak dapat lagi dicabut oleh ahli waris lainnya. 


\subsection{Proses Peralihan dan pembagian Harta Warisan}

Dalam pembagian harta warisan dikecamatan Sanggalangi khususnya di desa La'bo Kabupaten Tanah Toraja keputusan pewaris sangat menentukan atas kedududukan hartanya yang telah dinyatakan baik semasa hidupnya atau yang disebut Tekken, maupun yang diucapkan disaat terakhir menjelang ajal yang sering disebut dengan Ba'gi. Pada saat pewaris disaat terakhirnya ingin membagikan harta warisnya hal ini harus di hadiri oleh beberapa ahli waris atau keluarga yang terdekat pertalian keluarganya untuk turut menyaksikan peralihan tersebut.

Dalam peralihan tersebut biasanya pewaris memberikan pernyataan yang mengikat terhadap harta benda tertentu dari pada barang-barang peninggalan pewaris. Keputusan pewaris di kecamatan sanggalangi khususnya desa la'bo kabupaten tanah toraja dapat terbukti dalam bentuk-bentuk yang berupa Tekken atau penghibahan pernyataan kemauan terakhir yang disebut dengan Ba'gi atau hibah wasiat. Menurut hasil wawancara dengan sekertaris lembang yang bernama Ida Sanda, mengatakan bahwa : "pelaksanaan dari pada asas pewarisan dimasyarakat la'bo pada umumnya disesuaikan dengan waktu dan kebutuhan".

Artinya peralihan harta benda kepada ahli waris telah dilakukan pada waktu orang tua atau pewaris masih hidup karena kebutuhan anak itu, akan tetapi pembagiannya secara resmi menurut hukum akan dilakukan oleh kepala-kepala adat bilamana orang tua atau pewaris telah meninggal dunia. Oleh karena keputusan pewaris itu berhubungan dengan pewarisan maka hal-hal yang dibebankan pewaris disaat mengucapkan kemauan terakhir itu bila tidak terpenuhi jelas keputusan itu batal, misalnya seorang telah menerima bagian yang layak dari harta peninggalan sesuai dengan kemauan pewaris, ternyata tidak memenuhi tuntutan pewaris yang telah dibebankan baginya maka putusan itu dapat ditarik kembali, misalnya seorang telah menerima Tekken atau penghibaan maka ia mempunyai kewajiban untuk ikut dalam pelaksanaan penguburan mayat pewaris atau turut bertanggung jawab atas hutang-hutang pewaris akan tetapi ternyata penerima tekken itu hadir atau tidak mengambil bagian baik dalam penguburan mayat maupun pembayaran hutang-hutang pewaris maka keputusan atau pemberian Tekken itu batal atau ditarik kembali oleh ahli waris yang bertanggung jawab atas penguburan dan penyelesaian hutang-hutang pewaris.

\section{KESIMPULAN DAN SARAN}

\subsection{Kesimpulan}

1. Menurut hukum kewarisan adat dalam masyarakat Sangla'boran kedudukan anak terbagi menjagi enam : Anak Disibali (anak kandung), Anak Tangdisibali (Anak Pangngan, Anak Bule'), Anak Angkat, Anak Tiri, dan Anak Kemanakan. Dan pembagian harta warisan di kelompokkan dalam dua golongan yaitu golongan Sarume dan golongan Lu'pang. Golongan sarume adalah anak kandung yang menjadi ahli waris utama terhadap harta kekayaan orang tuanya. Sedangkan golongan Lu'pang adalah pengganti ahli waris utama, apabila ahli waris utama tidak ada.

2. Pada hakikatnya proses peralihan dan pembagian harta warisan di masyarakat Sanglaboran dibagi menjadi dua, yaitu Tekken, dan Ba'gi, atau Mana'. Tekken adalah pemberian harta warisan kepada ahli warisnya sebelum pewaris meninggal dunia dan pada saat itu juga penguasaan harta tersebut beralih secara langsung, sedangkan $B a^{\prime} g i$ atau Mana' adalah pembagian harta warisan kepada ahli warisnya pada saat pewaris meninggal dunia, yang dibagi secara merata dan peguasaan harta tersebut baru dapat beralih ketika pewaris meninggal dunia.

\subsection{Saran}

1. Karena banyaknya sengketa yang ditimbulkan akibat pewarisan baik dari golongan Sarume maupun golongan Lupang maka pemerintah diharapkan memberikan perhatian yang serius dengan cara turun langsung melakukan penyelidikan tidak hanya berdasarkan laporan yang masuk namun dengan sikap yang objektif dan penuh dengan rasa keadilan dan tanggung jawab.

2. Walaupun pembagian $B a^{\prime} g i$ atau Mana' di bagi secara merata, namun ada hal-hal tertentu yang menjadikan pertimbangan untuk anak sulung mendapatkan warisan yang nilainya lebih banyak dari saudara lainnya. Oleh karena itu untuk menghindari perselisihan yang terjadi di kemudian hari sebaiknya di buatkan aturan lebih lanjut tentang hak lain anak sulung tidak hanya dengan hasil musyawarah yang di tetapkan secara lisan, agar hak lain anak sulung tersebut tidak dapat diganggu gugat. 


\section{DAFTAR PUSTAKA}

Ali, Zainuddin. 2008. Pelaksanaan Hukum Waris di Indonesia. Cetakan ke-1. Sinar Grafika: Jakarta.

. 2010. Pelaksanaan Hukum Waris di Indonesia. Cetakan ke-2. Sinar Grafika: Jakarta.

Bastian Tapal 1981, Pengangkatan Anak dan Akibat Hukumnya di Kemudian Hari, Rajawali Press: Jakarta.

Djojodigoeno 1985. Azas-Asas Hukum Adat, Yayasan Penerbit Gajamada: Yogyakarta.

Hadikusuma, Hilman. 2003. Hukum Waris Adat. Cetakan Ke-7. Citra Aditya Bakti: Bandung 1983.Hukum Waris Adat, Alumni Bandung.

Harahap Parada. 1952. Rangkaian Tanah Air Toraja, N. Van Hoeven: Bandung.

Pide, Suriyaman Mustari. 2014. Hukum Adat Dahulu, Kini, dan Akan Datang. Cetakan ke-1. Prenadamedia Group: Jakarta.

Ritha Pong Masak. Hukum Kewarisan Adat Toraja Lepongan Bulan di Buntao' di Kecamatan Sanggalangi Tana Toraja. Skripsi pada Fakultas Hukum UKIP Makassar

Soepomo R, 1984. Bab-Bab Tentang Hukum Adat, Pradnya Paramita: Jakarta.

Tandilintin L.T. 2014. Toraja dan Kebudayaannya. Lembaga kajian dan penulisan Sejarah Budaya Sulawesi Selatan.

Ter Haar, Bzn B.1986. Asas-Asas Dan Susunan Hukum Adat. Terjemahan K.ng Subekti Poesponoto, Pradnya Paramita: Jakarta.

Tutik ,Titik Triwulan. 2010.Hukum perdata dalam sistem hukum nasional. Cet Ke-2. Kencana: Jakarta Wignjodipoero Soerojo, 1983. Pengantar dan Asas-asas Hukum Adat, PT. Gunung Agung : Jakarta 